\title{
The Effect of Yap Taz on Flexibility Exercise in Patient With Idiopathic Scoliosis
}

\section{Adelia Safira $^{1}$, Yenni Limyati ${ }^{2}$, Grace Puspasari $^{3}$}

1 Faculty of Medicine, Maranatha Christian University, Bandung, Indonesia

2 Department of Physical Medicine and Rehabilitation, Maranatha Christian University, Unggul Karsa Medika Hospital, Bandung, Indonesia

3 Departement of Biochemistry, Maranatha Christian University, Bandung, Indonesia

\begin{abstract}
During the outbreak of Covid-19, the policy of working from home for employees and studying from home for students create a new problem. Employees and students mostly have to sit for long periods of time. This can affect body posture leading to lower back pain. Scoliosis is a postural disorder consisting of lateral curvature and rotation of the vertebrae. The etiology of idiopathic scoliosis remains unknown, and still present as theoretical hypothesis's experts. One of non-surgical treatment that has been used for mild to moderate scoliosis is flexibility exercises. Flexibility exercises have been reported to reduce the degree of curvature in idiopathic scoliosis through the muscle hypertrophy mechanism. Muscle hypetrophy is regulated by Yes-associated protein (Yap) and transcriptional co-activator with PDZbinding motif protein (Taz) through three pathways, such as Hippo pathway signal, mechanosensor response, and mTOR signaling. The aim of this review is to examine more deeply the effect of Yap Taz protein on flexibility exercises in idiopathic scoliosis patients.
\end{abstract}

Keywords: flexibility, hypertrophy, scoliosis, Taz, Yap. 


\begin{abstract}
ABSTRAK
Di masa pandemi Covid-19, kebijakan bekerja dari rumah bagi pegawai dan belajar dari rumah bagi pelajar menimbulkan masalah baru. Para pegawai dan pelajar lebih banyak duduk di meja kerja dalam waktu yang lama. Hal ini dapat mempengaruhi postur tubuh yang menyebabkan nyeri punggung bawah. Skoliosis adalah kelainan postur berupa perubahan kelengkungan vertebra kearah lateral diikuti rotasi vertebra. Etiologi dari skoliosis idiopatik masih belum diketahui, dan masih berupa hipotesis teori dari para ahli. Salah satu tatalaksana non operatif ditujukan untuk skoliosis derajat ringan hingga sedang adalah latihan fleksibilitas. Latihan fleksibilitas terbukti dapat menurunkan derajat kurvatura pada skoliosis idiopatik melalui mekanisme hipertrofi otot. Hipetrofi otot diatur oleh protein Yes-associated protein (Yap) dan protein Transcriptional co-activator dengan PDZ-binding motif (Taz) melalui tiga jalur yaitu Hippo pathway signal, respon mechanosensor, dan mTOR signaling. Tujuan dari review ini adalah mengkaji lebih dalam pengaruh protein Yap Taz terhadap latihan fleksibilitas pada pasien skoliosis idiopatik.
\end{abstract}

Kata Kunci: fleksibilitas, hipertrofi, skoliosis, Taz, Yap.

\section{Correspondent Detail:}

\section{Yenni Limyati}

Email: y_nni@yahoo.com

Department of Physical Medicine and

Rehabilitation, Maranatha Christian

University, Unggul Karsa Medika Hospital,

Bandung, Indonesia

\section{INTRODUCTION}

In early 2020, the world, including Indonesia, was shocked by the coronavirus (Covid-19). Until now, the world still has to face the pandemic Covid-19. This disease is caused by infection with the SARS-CoV-2 coronavirus, which was initially identified in Wuhan, China but quickly spread to various countries, including Indonesia. ${ }^{1}$ Until March 25, 2021, the number of cases of Covid-19 virus infection in the world has reached $122,536,880$ cases.
Initially, the most cases were in China, but currently, the most cases are in the United States with 53,937,714 cases, followed by Brazil with 11,871,390 cases, and China with 102,523 cases. This virus has spread to 221 countries. Deaths due to the Covid-19 virus in the world have reached 2,703,780 cases. Whereas in Indonesia the number of Covid-19 cases has reached $1,455,788$ cases with the number of deaths due to Covid-19 of 39,447 cases. ${ }^{1}$

This coronavirus has various impacts on various sectors. In terms of the way people work, since the occurrence of COVID-19 in Indonesia, millions of Indonesians have been working from home for employees and studying from home for students. However, during working from home or WFH, the working hours become more irregular. Some employees or students may spend more time at work desks or sitting at work desks for a long time, if this is done in the long term it can affect posture so that it can cause disorders 
in the musculoskeletal system. ${ }^{2}$ A study by Hyo Jeong et al. reported that there was an association between prolonged use of gadgets and the onset of musculoskeletal disorders. Examples of musculoskeletal disorders include neck, shoulder, and back pain (low back pain). ${ }^{3}$

Back pain is one of the clinical symptoms of scoliosis, but non-specific back pain is very normal in $70 \%$ of the population, so not all back pain can be categorized as a clinical symptom of scoliosis. ${ }^{4}$ Scoliosis is a health problem that is often found in society. Scoliosis is a spinal deformity characterized by a lateral curvature of the spine or vertebral curvature accompanied by vertebral rotation. An X-ray of a person's vertebrae with scoliosis shows a "C" or "S" shape of the vertebrae. ${ }^{5}$ The diagnosis of scoliosis is confirmed if there is a curvature degree (Cobb angle) of at least $10^{\circ}$ on an X-ray of the anterior-posterior projection vertebra (AP). Scoliosis can manifest as mild, moderate, or severe scoliosis. Severe scoliosis can cause heart and lung function problems. ${ }^{6}$

The management of scoliosis is divided into two: non-operative and operative treatment depends on the severity of the disease, the degree of vertebral curvature, and the patient's age. ${ }^{6}$ One of the non-operative management of idiopathic scoliosis that can be done is flexibility exercises. Flexibility can be improved with a variety of exercises including yoga, pilates, Schroth exercises, Scientific Exercises Approach to Scoliosis (SEAS), and Functional Individual Therapy of Scoliosis (FITS). ${ }^{7}$

Flexibility exercises can cause muscle hypertrophy through the Hippo pathway signal mechanism regulated by Yes-associated protein
(Yap) protein and Transcriptional co-activator with PDZ-binding motive (Taz). By doing flexibility exercises, protein synthesis will increase, resulting in increased muscle mass or muscle hypertrophy. ${ }^{8}$ Muscle hypertrophy will reduce Cobb angle in scoliosis patients. By reducing the degree of curvature, the symptom of spinal pain in scoliosis patients can be reduced. ${ }^{9}$

The effect of Yap and Taz on muscle hypertrophy studied by Goodman, reported that overexpression of the Yap protein can cause muscle hypertrophy without passing the Mammalian Target of Rapamycin (mTOR) signaling. ${ }^{8}$ Judson et al. concluded that the active Yap protein will stimulate muscle hypertrophy. ${ }^{10}$ Research by Fishman and York stated that yoga with classic side plank movements for 6.8 months every 6 days a week with a duration of 1 hour per exercise session, can reduce Cobb angle in idiopathic and degenerative scoliosis patients. ${ }^{9}$ A research was done by Araújo et al. stated that pilates twice a week with a duration of one hour per training session, can reduce Cobb angle and reduce back pain in patients with non-structural scoliosis. ${ }^{11}$ Otman et al. concluded that Schroth exercises, which are performed five times a week with a duration of four hours per training session, can reduce Cobb angle, improve posture, and strengthen body muscles in idiopathic scoliosis patients. ${ }^{12}$ In this review, we will first introduce the hippo pathway signal, mTOR signaling, Mechanosensor Response Pathways as the background process of muscle hypertrophy. We will then discuss studies that support a link between core elements; Yap Taz protein and Flexibility Exercise. Next, we will review research that reports flexibility exercise is effective in the treatment of idiopathic scoliosis. 
Finally, the main intention of this review is to discuss the emerging Yap Taz link between the role of flexibility exercise as a non-operative treatment for idiopathic scoliosis.

\section{DISCUSSION}

\section{Hippo pathway signal}

Since 2010, several studies have observed the involvement of Hippo pathway signals in muscle mass regulation mechanisms, namely proliferation, regeneration, death, and growth of muscle cells. ${ }^{13}$

The core component of the Hippo pathway signal is the Hippo protein kinase. Hippo protein kinase consists of Mammalian sterile-20 kinase 1/2 (MST 1/2), Mitogen-activated protein kinase kinase kinase (MAP4K 1-4), Large Tumor Suppressor kinase 1/2 (LATS 1/2), Nuclear Dbf2related 1/2 (NDR 1/2). Warts explained that the core component of the Hippo pathway signal identified in Drosophila and mammals is LATS $1 / 2$. Hippo protein kinase becomes active when it undergoes phosphorylation. The activation of the Hippo protein kinase is stimulated by three elements, namely: mechanical elements (mechanotransduction, dystroglycoprotein complex), hormonal elements (glucocorticoids, estrogens), and metabolic elements (AMPK1, glucose). The active LATS $1 / 2$ protein will inhibit Yap and Taz proteins from entering the cell nucleus by phosphorylating Yap protein in serine (S)127 and Taz protein in serine (S)89 in HXRXXS. Phosphorylation of Yap and Taz proteins will maintain these proteins in the cytoplasm. ${ }^{13,14}$

When Yap protein active it will increase the size of muscle cells, without increasing the number of muscle cells. Yap and Taz proteins become active through dephosphorylation so Yap and Taz proteins can enter the cell nucleus. In the cell nucleus, the Yap and Taz proteins will interact with the transcription factor Tead (Tead 1-4). Yap and Taz proteins will increase protein synthesis, satellite cell proliferation, and muscle fiber growth resulting in skeletal muscle hypertrophy. ${ }^{15}$

Protein Yes-associated protein (Yap) and transcriptional co-activator with PDZ-binding motive (Taz) regulate fiber growth skeletal muscle, while the Hippo protein kinase such as, MST1/2, MAP4K1-4, LATS1/2, NDR1/2 proteins inhibit the growth of skeletal muscle fibers. Therefore, Yap and Taz proteins are important regulators in the growth of skeletal muscle mass. Flexibility exercises will increase the expression of Yap and Taz proteins resulting stimulate protein synthesis in skeletal muscle. Flexibility exercise is included in resistance exercise which is one of the mechanical stimuli in stimulating the phosphorylation of Hippo protein kinase. ${ }^{15}$ The schematic of this Hippo pathway signal can be seen in Figure 1. Another hypothesis also suggests that Yap and Taz proteins stimulate protein synthesis and hypertrophy of skeletal muscle through the independent mechanism of Mechanistic Target of Rapamycin (mTOR) signaling. Thus there will be the growth of muscle fibers resulting in hypertrophy of the skeletal muscles. ${ }^{14}$

\section{Mechanosensor Response Pathways Flexibility exercise is an example of resistance exercise.}

Muscle hypertrophy is the main response to resistance exercise. Flexibility exercises will increase protein synthesis and protein breakdown. 
When eating, protein synthesis occurs more than protein breakdown, leading to protein gain and hypertrophy. The Höhfeld group identified a specific Hippo complex and autophagy-regulating mechanosensor located on disk Z. Protein Bag 3 in disk $\mathrm{Z}$ in the Hippo complex and autophagy, are mediators of the mechanosensor response that directly / independently cause muscle contraction and increase protein breakdown during resistance exercise such as flexibility exercise. In addition, Protein Bag 3 binds to the Hippo protein kinase Lats1 / 2, causing activation of Yap and Taz proteins which causes skeletal muscle hypertrophy. The binding of Protein Bag 3 and Hippo protein kinase is one of the mechanisms for regulating the growth of muscle fibers due to mechanical stimuli (resistance exercises). ${ }^{8,14}$

\section{mTOR signaling pathway}

Baar and Esser first associated muscle fiber growth with mTOR signaling. They showed that the occurrence of mTOR phosphorylation and the related kinase p70 S6k correlated with increased muscle mass in the mouse muscle simulation model. Since then, many studies have reported the role of mTOR signaling in muscle hypertrophy in resistance exercises.
A study done in human have shown that the mTORC1 inhibitor rapamycin prevents muscle protein synthesis in resistance exercises. The main mediator in muscle protein synthesis is mTOR signaling through the inhibition mechanism mTORC1 inhibitor rapamycin to increase muscle protein synthesis in resistance exercises. So it can be concluded that the Hippo pathway signal and mTOR signaling can run simultaneously because of the various mechanisms that occur therein. ${ }^{16}$

\section{Relationship between Yap and Taz with Flexibility Exercises}

Spencer and Eccles explained that there are abnormalities of the paraspinal muscles in idiopathic scoliosis patients. There are two types of paraspinal muscle fibers, namely, type 1 (slowtwitch) and type II (fast-twitch). In idiopathic scoliosis patients, it is found that the number of paraspinal type II muscle fibers is reduced, resulting in myopathic processes and muscle atrophy. ${ }^{17}$ Hopefully by resistance exercise, muscle hypertrophy occurs through increased Yap and Taz proteins through these various mechanisms, resulting in decrease of Cobb angle in a patient with idiopathic scoliosis. ${ }^{14}$

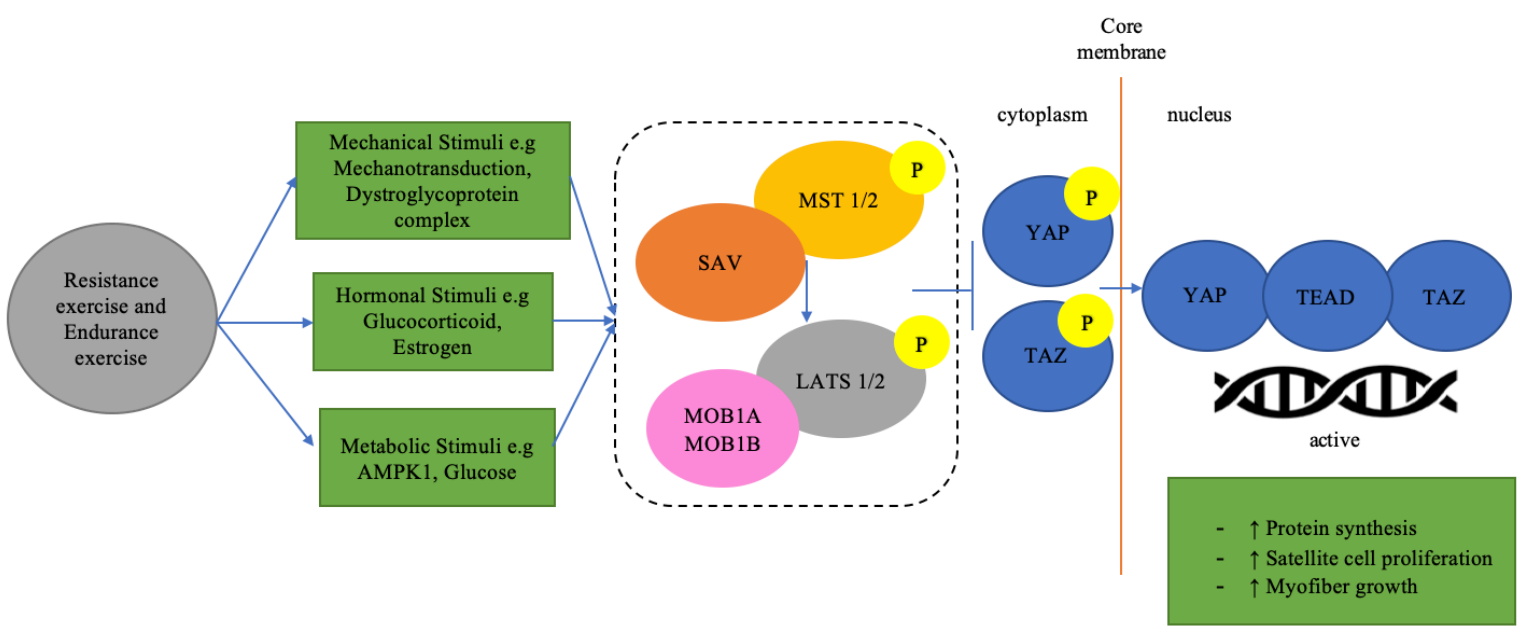

Figure 1. Schematic of the Hippo pathway signal Hippo pathway in stimulating muscle hypertrophy 
Research that supports the effect of Yap and Taz on Flexibility Exercise

The effect of Yap Taz protein on muscle hypertrophy due to mechanical stimuli has been widely studied by researchers. Goodman et al. conducted the first study on mice that showed increased Yap protein expression in response to mechanical stimuli. This study uses a synergist ablation (SA) model. There is a progressive increase in total Yap protein with a peak of 4-5 times on day 7 since the first onset, and there was an increase in Yap protein phosphorylation at (S) 112. Goodman et al. concluded that the Hippo pathway signal, especially the Lats $1 / 2$ protein kinase, is sensitive to mechanical stimuli in skeletal muscle. ${ }^{8}$

Watts et al. reported that Yap protein is a core component of the Hippo pathway signal that regulates cell/tissue proliferation and apoptosis and Yap protein positively regulates skeletal muscle mass \& protein synthesis by binding to the transcription factor Tead. A study by Watts et al. concluded that Yap protein levels decreased during the maturity of skeletal muscle fibers and Yap protein was needed to maintain the size (mass) of skeletal muscle fibers. The Yap protein stimulates muscle hypertrophy by binding with the transcription factor Tead, and Watts et al.

Found that the Yap protein decreased in response to skeletal muscle atrophy due to neuromuscular disease. ${ }^{18}$

\section{Flexibility Exercises in Idiopathic Scoliosis Patients}

There are various types of intervention in scoliosis treatment, not all scoliosis requires surgery for example moderate-degree juvenile scoliosis, the recommended therapy is Physiotherapic scoliosis-specific exercise (PSSE). The Society on Scoliosis Orthopedic \& Rehabilitation Treatment (SOSORT) 2016 states that PSSE is a specific exercise for scoliosis with self-correcting methods in three-dimensional fields. Flexibility exercise is various types of exercises performed by idiopathic scoliosis patients to strengthen the muscles, prevent muscle atrophy, increasing flexibility, and improving the patient's posture. One example of flexibility exercises is the PSSE with various methods such as Schroth and SEAS. ${ }^{19}$ Some examples of flexibility exercises that will be discussed are yoga, pilates, Schroth, SEAS, and FITS. Yoga comes from the Sanskrit language "yuj" which means to unite. Yoga is a practice that unites the human body, mind, and soul into balance. Yoga has many benefits, one of which, increases muscle strength, endurance, stamina, and can help improve sleep quality. The effect of yoga on idiopathic scoliosis has been studied by Fishman et al. They have researched 25 patients with idiopathic and degenerative scoliosis who were asked to routinely do yoga with classic side plank Iyengar movements for 6.8 months every 6 days a week. The results obtained in 7 idiopathic scoliosis patients showed a decrease in the mean Cobb angle on the primary curve from $22.8^{\circ}$ to $11.2^{\circ} \cdot{ }^{20}$

Pilates is an exercise method that combines yoga, resistance exercise, strengthening muscles, and improving balance. Pilates generally use a variety of tools such as mattresses, chairs, trapeze tables, ladder barrels, reformers, etc. 11 Research conducted by Gichul et al. showed that there was a decrease in Cobb angle in 24 idiopathic scoliosis patients, divided into 12 
patients doing Pilates exercises and 12 patients doing Schroth exercises. Pilates was carried out for 12 weeks with a frequency of three times a week. A significant result in the pilates exercise group was a decrease in the mean Cobb angle from $24^{\circ}$ to $16^{\circ} .{ }^{21}$

Schroth exercise has the principle of forming the opposite effect of those shown on the body of a scoliosis patient. Schroth does not resemble regular exercise, there is an exclusive corrective breathing technique called rotational breathing. Schroth exercise uses a three-dimensional approach treatment based on a lateralized curve. ${ }^{22}$ Research conducted by Kuru et al. examined 45 scoliosis patients with 15 patients doing Schroth exercises under professional instructors, 15 patients doing independent Schroth exercises at home, and 15 patients as a control group. Schroth exercises were carried out for 6 months with a frequency of 3 times per week and a duration of 1.5 hours per training session. Kuru et al. reported there is a decrease in Cobb angle of $2.53^{\circ}$ and vertebral rotational angle of $4.23^{\circ}$ in the group that did Schroth exercises with the help of a professional physiotherapist, while in the group that did therapy individually at home there was no significant change. ${ }^{23}$ Schreiber conducted a study on the effect of the Schroth method combines with standard treatment of scoliosis. Schroth exercise was carried out for 6 months and the results were obtained, in the exercise group there was a decrease in Cobb angle on the largest curve by $1.4^{\circ}$ and in the total Cobb angle, there was a decrease by $2.5^{\circ}$. Meanwhile, the standard treatment group experienced progressivity, the Cobb angle on the largest curve increased by $1.2^{\circ}$ and the total Cobb angle increased by $3.2^{\circ}$. Scheiber et al. concluded that the Schroth PSSE method has a positive effect both on the Cobb angle on the largest curve, and in total. ${ }^{24}$

Scientific Exercise Approach for Scoliosis (SEAS) was first developed in the 1960s in Italy by Antonio Negrini and Nevia Verzini. SEAS exercises have two main objectives; improve spinal stability function and improve related functions, for example, the strength and elasticity of certain muscles and neuromotor abilities such as body balance. ${ }^{25}$ Negrini et al. conducted a study on 74 idiopathic scoliosis patients with a mean age of 12.1 years and a Cobb angle of $15^{\circ}$. Patients were allowed to choose between two groups; SEAS exercise and regular physiotherapy, these two groups' intervention was carried out for 12 months with frequency twice per week and the duration is 1.5 hours per training session. The result obtains in the SEAS group there was a decrease in Cobb angle compared to the physiotherapy group, which got worse. Negrini concluded that SEAS was more effective than regular physiotherapy. However, the Cobb angle changes of $-0.67^{\circ}$ in the SEAS and $+1.38^{\circ}$ in the physiotherapy group were considered too small to conclude that SEAS was effective in the treatment of idiopathic scoliosis. ${ }^{26}$

Functional Individual Therapy of Scoliosis (FITS) was first discovered by Marianna Bialek and Andrzej M'hango in 2004 as a therapy for scoliosis. In FITS, there are three main stages; initial examination, preparation, and relaxation of myofascial restrictions that may limit three-dimensional correction, and three-dimensional correction exercises in functional positions. Bialek studied 115 scoliosis patients, the patients were divided 
into two groups based on Cobb angle, group A $10-25^{\circ}$ and group B $26-40^{\circ}$. Patients were studied for 2.08 years (range 1-5 years), the exercises were carried out every month with a duration of 60 minutes per training session. The results found in group A were: (1) in single curve scoliosis, $50 \%$ of patients improved, $46.2 \%$ were stable, and $3.8 \%$ were developing, (2) in multiple curve scoliosis, it was found that $50 \%$ of patients were improving, $30.8 \%$ were stable, and 19.2\% developing. Whereas in group B, the results were: (1) single curve scoliosis, $20 \%$ of patients improved, $80 \%$ were stable, (2) in double curve scoliosis $28.1 \%$ of patients improved, $46.9 \%$ were stable, and $25 \%$ developed. Bialek concluded that FITS is an effective therapy for scoliosis, especially low-grade idiopathic scoliosis. ${ }^{27}$

Other studies that support the effect of flexibility exercise on idiopathic scoliosis, one of which is the study by Toledo et al., reported that the PSSE Global postural re-education (GPR) method significantly reduced Cobb angle by about $5.3^{\circ}$ after 12 weeks of exercise intervention. ${ }^{28}$ Scheiber et al. examined the effect of Schroth's exercise intervention on idiopathic scoliosis. The results obtained, the Schroth group experienced a decrease in Cobb angle on the largest curve by $1.4^{\circ}$ and in the total Cobb angle there was a decrease of as much as $2.5^{\circ} .{ }^{24}$ Romano et al. examined the effect of non-operative therapy, namely SEAS and brace use in idiopathic scoliosis with a Cobb angle of $10-20^{\circ}$. The results showed that the brace group experienced an improvement in Cobb angle in $45 \%$ of patients and $10 \%$ experienced progressivity, while the group with SEAS exercise $30 \%$ experienced improvement and $16 \%$ experienced progression. ${ }^{29}$ Several reviews on flexibility exercises are attached in Table 1.

Table 1. Review of Flexibility Exercises Flexibility

\begin{tabular}{llll}
\hline $\begin{array}{c}\text { Flexibility } \\
\text { exercises }\end{array}$ & \multicolumn{1}{c}{ Results of Cobb Angle } & Duration & Author and Year \\
\hline SEAS & $\downarrow$ cobb angle on the largest curve $0.33^{0}$ & 3 months & Negrini et al., 2008. ${ }^{26}$ \\
& $\downarrow$ total cobb angle $0.67^{0}$ & & \\
Schroth & $\downarrow$ cobb angle $2.53^{0}$ & 6 months & Kuru et al., 2015. ${ }^{23}$ \\
FITS & Group A $\left(10^{0}-25^{\circ}\right): \downarrow 4.7^{0}$ & 2.08 years & Bialek et al., 2011.27 \\
& Group B $\left(26^{0}-40^{\circ}\right): \downarrow 0.9^{0}$ & & \\
Yoga & $\downarrow$ average of cobb angle from $22.8^{0}$ to $11.2^{0}$ & 9.4 months & Fishman et al., 2014. ${ }^{20}$ \\
Schroth & $\downarrow$ cobb angle on the largest curve $1.4^{0}$ & 6 months & Schreiber et al., 2016. ${ }^{24}$ \\
& $\downarrow$ total cobb angle $2.5^{0}$ & & \\
Pilates & $\downarrow$ cobb angle from $24^{0}$ to $16^{0}$ & 3 months & Gichul et al.,2016. ${ }^{21}$ \\
Schroth & $\downarrow$ cobb angle from $23.6^{0}$ to $12^{0}$ & 3 months & Gichul et al.,2016. ${ }^{21}$ \\
\hline
\end{tabular}




\section{CONCLUSION}

Yap and Taz proteins play a role in resistance exercise through various pathways, such as Hippo pathway signals, mTOR signaling, and mechanosensor response that induce muscle hypertrophy. The response of flexibility exercise in the form of muscle hypertrophy is effective in reducing Cobb angle in low to moderate degrees of idiopathic scoliosis patients.

\section{REFERENCES}

1. Coronavirus Disease (COVID-19) Situation Reports [Internet]. [cited 2021 Mar 25]. Available from: https://www. who.int/emergencies/diseases/novelcoronavirus-2019/situation-reports

2. Aytar A, Altintaş A, Aytar A. Effects of posture and ergonomics training for students receiving distance education during the covid-19 pandemic on musculoskeletal pain, exercise behavior decision-making balance, and physical activity level. J Exerc Ther Rehabil 2020; 7: 137-44.

3. Kim HJ, Kim JS. The relationship between smartphone use and subjective musculoskeletal symptoms and university students. J Phys Ther Sci 2015; 27: 575-9.

4. Solomon L, Warwick D, Nayagam S. Apley's system of Orthopaedics and Fracture. Ninth Edit. UK: Hodder Arnold 2010; 459-465 p.

5. Scoliosis | Scoliosis Research Society [Internet]. [cited 2020 Jul 1]. Available from: https://www.srs.org/patients-andfamilies/conditions-and-treatments/ parents/scoliosis

6. Janicki JA, Frcsc BA. Scoliosis : Review of diagnosis and treatment. Paedriatric Child Heal 2017; 12: 771-6.

7. Kim HS. Evidence-based of nonoperative treatment in adolescent idiopathic scoliosis. Asian Spine J 2014; 8: 695-702.

8. Craig A G, Jason M D, Brittany L J, Rachel M M, You J-S, and Troy A H. Yes-associated protein is up-regulated by mechanical overload and is sufficient to induce skeletal muscle hypertrophy. Physiol Behav 2015; 176: 139-48.

9. Fishman LM, York N, System DH, Sherman KJ, Health G. Serial Case Reporting yoga for Idiopathic and degenerative Scoliosis. Cit Glob Adv Heal Med 2014; 3: 16-21.

10. Judson RN, Tremblay AM, Knopp P, White RB, Urcia R, De Bari C, et al. The hippo pathway member Yap plays a key role in influencing fate decisions in muscle satellite cells. J Cell Sci 2012; 125: 600919.

11. Alves de Araújo ME, Bezerra da Silva E, Bragade Mello D, Cader SA, Shiguemi Inoue Salgado A, Dantas EHM. The effectiveness of the Pilates method: Reducing the degree of non-structural scoliosis, and improving flexibility and pain in female college students. J Bodyw Mov Ther 2012; 16: 191-8.

12. Otman S, Kose N, Yakut Y. The efficacy of Schroth's 3-dimensional exercise therapy in the treatment of adolescent idiopathic scoliosis in Turkey. Neurosciences 2005; 10: $277-83$. 
13. Gnimassou O, Francaux M, Deldicque L. Hippo pathway and skeletal muscle mass regulation in mammals: A controversial relationship. Front Physiol 2017; 8: 1-6.

14. Gabriel BM, Lee Hamilton D, Tremblay AM, Wackerhage H. The Hippo signal transduction network for exercise physiologists. J Appl Physiol 2016; 120: 1105-17.

15. Watt KI, Goodman CA, Hornberger TA, Gregorevic P. The Hippo Signaling Pathway in the Regulation of Skeletal Muscle Mass and Function. Exerc Sport Sci Rev 2018; 46: 92-6.

16. Gabriel BM, Lee Hamilton D, Tremblay AM, Wackerhage H. The Hippo signal transduction network for exercise physiologists. J Appl Physiol 2016; 120: 1105-17.

17. Cheung KMC, Wang T, Qiu GX, Luk KDK. Recent advances in the aetiology of adolescent idiopathic scoliosis. Int Orthop 2008; 32: 729-34.

18. Watt KI, Turner BJ, Hagg A, Zhang X, Davey JR, Qian H, et al. The Hippo pathway effector YAP is a critical regulator of skeletal muscle fibre size. Nat Commun $2015 ; 6$.

19. Pelealu J, Angliadi LS, Angliadi E. Rehabilitasi Medik Pada Skoliosis. J Biomedik 2014; 6: 8-13.

20. Fishman LM, Groessl EJ, Sherman KJ. Serial Case Reporting Yoga for Idiopathic and Degenerative Scoliosis. Glob Adv Heal Med 2014; 3: 16-21.

21. Kim G, Hwangbo PN. Effects of schroth and pilates exercises on the cobb angle and weight distribution of patients with scoliosis. J Phys Ther Sci 2016; 28: 1012-5.

22. Bezalel T, Carmeli E, Levi D, Kalichman L. The effect of schroth therapy on thoracic kyphotic curve and quality of life in scheuermann's patients: A randomized controlled trial. Asian Spine J 2019; 13: 490-9.

23. Kuru T, Yeldan Ï, Dereli EE, Özdinçler AR, Dikici FATIH, Çolak Ï. The efficacy of three-dimensional Schroth exercises in adolescent idiopathic scoliosis: A randomised controlled clinical trial. Clin Rehabil 2015; 30: 181-90.

24. Schreiber S, Parent EC, Moez EK, Hedden DM, Hill DL, Moreau M, et al. Schroth physiotherapeutic scoliosis-specific exercises added to the standard of care lead to better cobb angle outcomes in adolescents with idiopathic scoliosis - An assessor and statistician blinded randomized controlled trial. PLoS One 2016; 11: 1-17.

25. Romano M, Negrini A, Parzini S, Tavernaro M, Zaina F, Donzelli S, et al. SEAS (Scientific Exercises Approach to Scoliosis): A modern and effective evidence based approach to physiotherapic specific scoliosis exercises. Scoliosis 2015; 10: 1-19.

26. Negrini S, Zaina F, Romano M, Negrini A, Parzini S. Specific exercises reduce brace prescription in adolescent idiopathic scoliosis: A prospective controlled cohort study with worst-case analysis. J Rehabil Med 2008; 40: 451-5.

27. Białek M. Conservative treatment of idiopathic scoliosis according to FITS concept: Presentation of the method and preliminary, short term radiological and 
clinical results based on SOSORT and SRS criteria. Scoliosis 2011; 6: 1-19.

28. Negrini S, Donzelli S, Aulisa AG, Czaprowski D, Schreiber S, de Mauroy JC, et al. 2016 SOSORT guidelines: Orthopaedic and rehabilitation treatment of idiopathic scoliosis during growth. Vol. 13, Scoliosis and Spinal Disorders. Scoliosis and Spinal Disorders 2018; 1-48 p.

29. Zaina F, Negrini S, Atanasio S, Fusco C, Romano M, Negrini A. Specific exercises performed in the period of brace weaning can avoid loss of correction in adolescent idiopathic scoliosis (AIS) patients: Winner of SOSORT's 2008 award for best clinical paper. Scoliosis 2009; 4: 7-12. 